The Science of the Total Environment

Elsevier Publishing Company, Amsterdam - Printed in Belgium

\title{
POTENTIALLY HAZARDOUS SUBSTANCES IN SURFACE WATERS
}

PART I. PESTICIDES IN THE RIVER RHINE*

\section{P. A. GREVE}

Laboratory for Toxicology, National Institute of Public Health, Utrecht (The Netherlands)

(Received May 25th, 1972)

\section{ABSTRACT}

In this paper, some initial results of a monitoring program with respect to toxic substances in the river Rhine are presented together with experimental details on the analytical methods used. The results cover the period, September 1969-March 1972.

$\alpha$-Benzenehexachloride ( $\alpha-\mathrm{BHC}), \gamma-\mathrm{BHC}$ or lindane, and hexachlorobenzene (HCB) are nearly always present in the Rhine. The concentration of these substances in the river is about ten times as high as in typically "agricultural" surface waters. Endosulfan, an insecticide which had been found in the river Rhine in several "waves" during the years 1969 and 1970, has been rarely found in that river since July, 1970. The other organochlorine pesticides and their metabolites (heptachlor, -epoxide, aldrin, dieldrin, endrin and DDT-complex) have occasionally been found, but only in low concentrations. Polychlorinated biphenyls (PCB's) have not yet been found in detectable amounts, i.e. $<0.5 \mu \mathrm{g} /$ liter. Cholinesterase inhibitors are always present in the Rhine, and their occurrence is typical for the Rhine and its tributaries.

\section{INTRODUCTION}

Since September 8 th, 1969, samples from the river Rhine have been investigated in the National Institute of Public Health (Utrecht, The Netherlands) for the presence of potentially hazardous substances. The samples were taken three times a week at Rhine kilometer 883 (upstream from Nijmegen in the Waal river, the main branch of the Rhine river in the Netherlands).

The results of this monitoring program are presented with respect to the organochlorine pesticides (and some related substances) and the cholinesterase inhibitors.

\footnotetext{
-This is an extended and updated version of a lecture for the "Internationale Arbeitsgemeinschaft der Wasserwerke im Rheineinzugsgebiet" (IAWR), Rotterdam, October, 1971.
} 
The water samples were analyzed for the following substances:

(a) The $C_{6}$-compounds benzenehexachloride (BHC) and hexachlorobenzene (HCB). Several isomers of BHC are possible. Only the $\gamma$-isomer (lindane) has insecticidal properties. $\alpha-\mathrm{BHC}$ is the main side product of the synthesis of lindane. HCB is used, inter alia, as a fungicide.

(b) The alicyclic compounds endrin, aldrin, dieldrin, heptachlor and endosulfan. All five compounds are insecticides. The main metabolite of heptachlor, heptachlorepoxide, is also currently being determined.

(c) The DDT-complexes, the main representatives of which are; $p, p^{\prime}$-DDT (the insecticide proper), $o, p^{\prime}$-DDT (the main contaminant in "technical" DDT), $p, p^{\prime}$-DDD, and $p, p^{\prime}-\mathrm{DDE}$ (the two main metabolites of $p, p^{\prime}$-DDT).

(d) The cholinesterase inhibitors. To this large group of insecticides belong esters of phosphoric acid (e.g. dichlorvos), of thio-phosphoric acid (e.g. parathion), of dithiophosphoric acid (e.g. malathion) and of carbamic acid (e.g. carbaryl). The biochemical action, viz. the inhibition of the enzyme cholinesterase, is common to all members of this chemically very diverse group.

\section{Organochlorine pesticides}

The organochlorine pesticides were determined by gas chromatography in a petroleum ether extract of the sample. In general, clean-up over Florisil ${ }^{1}$ or silica gel $^{2}$ was necessary.

\section{Method}

The water sample ( $500 \mathrm{ml}$, inclusive of silt) was extracted with 100,50 and $50-\mathrm{ml}$ portions of petroleum ether (boiling range $40-60^{\circ} \mathrm{C}$ ). The combined extracts were dried on calcinated $\mathrm{Na}_{2} \mathrm{SO}_{4}$ and concentrated to about $5 \mathrm{ml}$ in a KudernaDanish apparatus. The concentrated extract was brought onto a Florisil column (see Remarks) and elution was carried out with petroleum ether $(50 \mathrm{ml})$ and a petroleum ether-ethyl ether mixture $(94: 6, \mathrm{v} / \mathrm{v}, 100 \mathrm{ml})$. These two eluates together form "Eluate I". Elution was continued with a petroleum ether-ethyl ether mixture $(85: 15,200 \mathrm{ml})$. This eluate forms "Eluate II". During the whole procedure the elution speed was regulated at about $4 \mathrm{ml} / \mathrm{min}$.

After concentration in a Kuderna-Danish apparatus, the eluates were ultimately evaporated to dryness at room temperature with a gentle nitrogen stream (it is recommended to add a few drops of $n$-hexadecane if the sample is relatively clean, as otherwise losses of volatile pesticides might occur). The residues were dissolved in exactly $1 \mathrm{ml}$ of ethyl acetate or $\mathrm{n}$-hexane. This solution $(1 \mu \mathrm{l})$ was then injected into the gas chromatograph under the following conditions: Column, Pyrex, $5 \times 1 / 8$ in. O.D. Filling, $10 \%$ QF-1 (or OV 210)/10\% OV-17, 4:1, on Chromosorb-W HP, 80-100 mesh; or 3\% DEGS $+1 \% \mathrm{H}_{3} \mathrm{PO}_{4}$ on Gaschrom-Q, 100-120 mesh. Carrier gas, nitrogen, about $40 \mathrm{ml} / \mathrm{min}$. Temperature of the column; $\sim 200^{\circ} \mathrm{C}$ for the 
QF-1/OV-17 phase, and $\sim 170^{\circ} \mathrm{C}$ for the DEGS phase. Detector, $\mathrm{H}^{3}$-electron capture detector.

In Eluate I, were present (in the order of appearance from the QF-1/OV-17 phase): HCB, $\alpha-, \gamma-, \beta$-BHC (together with heptachlor), aldrin, heptachlorepoxide, $p, p^{\prime}$-DDE, $o, p^{\prime}$-DDT, $p, p^{\prime}$-DDD and $p, p^{\prime}$-DDT. From DEGS the order was: HCB, aldrin, heptachlor, $\alpha$-BHC, $\gamma$-BHC, heptachlorepoxide, $p, p^{\prime}$-DDE, $o, p^{\prime}$-DDT, $\beta$-BHC, $p, p^{\prime}$-DDT and $p, p^{\prime}$-DDD.

In Eluate II only dieldrin and endrin were present.

\section{Remarks}

(1) Florisil-PR was used throughout. The material must be activated at $130^{\circ} \mathrm{C}$ for $16 \mathrm{~h}$, and must be used within one day after activation. The Florisil was brought as a slurry to the chromatographic column partly filled with petroleum ether.

(2) The amount of Florisil was calculated from the "lauryl number" 1 . If the lauryl number was $100,16 \mathrm{~g}$ were taken; if the lauryl number was $80,20 \mathrm{~g}$, etc.

(3) The procedure described above was valid for all organochlorine pesticides except endosulfan. Endosulfan is always determined in a separate extract according to the procedure described in Ref. 2.

\section{Cholinesterase inhibitors}

The cholinesterase inhibitors were determined in a methylene chloride extract of the sample. Two methods were used: a thin-layer chromatographic method ${ }^{3}$ and a colorimetric method ${ }^{4}$. The thin-layer chromatographic method gives a separation in components, but (at best) only semi-quantitative evaluation. The colorimetric method gives a quantitative measure for the total cholinesterase inhibitory capacity of the sample. It must be expressed in an arbitrarily chosen standard substance, for which paraoxon proved to be suitable.

Thin-layer chromatography (t.l.c.)

The water sample $(500 \mathrm{ml}$, inclusive of silt) was extracted with 100,50 and $50-\mathrm{ml}$ portions of $\mathrm{CH}_{2} \mathrm{Cl}_{2}$. The combined extracts were dried on calcinated $\mathrm{Na}_{2} \mathrm{SO}_{4}$, concentrated to about $5 \mathrm{ml}$ in a Kuderna-Danish apparatus and evaporated to dryness at room temperature with a gentle nitrogen stream. The residue was dissolved in exactly $0.5 \mathrm{ml}$ of $\mathrm{CH}_{2} \mathrm{Cl}_{2}$, and from this solution, $10 \mu \mathrm{l}$ (in portions of $5 \mu \mathrm{l}$ ) were brought onto a $0.5-\mathrm{mm}$ thick silica gel layer. Between the unknowns, solutions of standard substances were brought onto the plate. Suitable standard substances are (recommended amount to be brought on the plate in parentheses): carbaryl $(0.5 \mathrm{ng})$, malathion (1 ng), phosalone (1 ng), parathion (1 ng) and carbophenothion $(2.5 \mathrm{ng})$. The amounts indicated were easily detectable.

The plate was placed in a chromatographic tank. The solvent used was either benzene or a mixture of benzene-acetone-n-hexane (10:25:65). When the front was at a height of about $14 \mathrm{~cm}$, the plate was taken from the tank and dried in the air. It is recommended to let the chromatography take place in an unsaturated atmosphere (i.e. to clean the tank after use). 
The plate was then placed for 30 seconds in a desiccator of about 151 , in which was present $0.1 \mathrm{ml}$ of bromine vapour. The atmosphere in the desiccator must be kept saturated throughout with water vapour. During the bromine treatment the $P=S$-esters are oxidized to $P=O$-esters, which generally have a higher cholinesterase inhibiting capacity. The sensitivity of the method towards the organic thiophosphates and dithiophosphates is increased in this way; the oxidation step has no advantages (sometimes even disadvantages) for organic phosphates and carbamates.

The plate was placed in the open air until the smell of bromine had disappeared and than sprayed with a homogenate of about 25 bee heads $^{5}$ in $75 \mathrm{ml}$ of ice-water. For each plate of $20 \times 20 \mathrm{~cm}, 15-20 \mathrm{ml}$ of this solution was needed. The bee heads can be stored without significant loss of activity for at least one year if kept at about $-20^{\circ} \mathrm{C}$. The homogenate must be freshly prepared every day.

The plate was placed in an incubator at $37^{\circ} \mathrm{C}$. The atmosphere in the incubator must be kept saturated with water vapour. The incubation took $30 \mathrm{~min}$.

In the meantime, $\beta$-naphthylacetate $(20 \mathrm{mg})$ was dissolved in $96 \%$-ethanol $(8 \mathrm{ml})$ and Fast Blue B $(50 \mathrm{mg})$ was dissolved in water $(32 \mathrm{ml})$. The two solutions were mixed and $5 \mathrm{ml}$ of this mixture was sprayed on the plate, which was then incubated again. After 15-30 min, the colour was stable.

The cholinesterase inhibitors appeared as white spots on a pink background.

\section{Colorimetric method}

Extraction, concentration and evaporation were carried out as described in the section on t.l.c. The residue was, however, dissolved in acetone $(0.5 \mathrm{ml})$ and this solution was diluted with water to $10 \mathrm{ml}$ in a volumetric fiask.

This solution $(5 \mathrm{ml})$ was oxidized with diluted bromine water: initially, saturated bromine water $(0.5 \mathrm{ml})$ was diluted to $10 \mathrm{ml}$ with water and one drop of this solution was used for the oxidation. After $15 \mathrm{~min}$ the oxidation was stopped by the addition of one drop of $1 \%$ albumine solution. The remaining $5 \mathrm{ml}$ of the sample can be measured directly in order to differentiate between $\mathrm{P}=\mathrm{S}$ - and $\mathrm{P}=\mathrm{O}$-esters (respectively carbamates).

The colorimetric determination is conveniently carried out on an AutoAnalyzer ${ }^{4}$. With this instrument, 50-60 samples can be handled easily in one day. Also, the reproducibility is better than if manual methods are used.

The reagents used were as follows:

(a) Buffer solution: trishydroxymethylaminomethane (3.634 g), $\mathrm{NaCl}(17.55 \mathrm{~g})$ and BRIJ $35(1 \mathrm{ml})$ were dissolved in water $(1000 \mathrm{ml})$ at a $\mathrm{pH}$ of 7.4.

(b) Plasma solution: freeze-dried human plasma was dissolved in water and filtered, and an aliquot of this solution was used in the determination so that the base line of the colorimeter lies at $10-20 \%$ transmission. The enzyme solution must be prepared freshly every day and must be kept in ice-water during the whole determination.

(c) Substrate: acetylthiocholine-iodide $(1.0 \mathrm{~g})$ was dissolved in water $(700 \mathrm{ml})$. This solution also had to be kept ice-cold during the determination. 
(d) Reagent: dithio-bis-nitrobenzoic acid $(600 \mathrm{mg})$ was dissolved in water ( $\sim 900 \mathrm{ml}$ ). The $\mathrm{pH}$ was brought to 7.4 with diluted $\mathrm{NaOH}$ under vigorous stirring: the $\mathrm{pH}$ must not, even locally, come higher than 9 . When the $\mathrm{pH}$ was adjusted, the volume was brought to exactly $1000 \mathrm{ml}$ with water.

(e) Standard solution: parathion, $10 \mu \mathrm{g} /$ liter.

(f) Rinsing liquid: distilled water containing approx. $0.1 \mathrm{ml}$ of BRIJ 35. Ref. 4.

The pumping scheme and other devices were the same as those described in

\section{RESULTS}

The several thousand data already collected in the monitoring program are summarized in Table I. In this table are given: the incidence rate (i.e. the amount of samples with concentrations above the detection limit, expressed in percents of the total amount); the detection limit; the average; the median; the upper and lower deciles; and the minimum and maximum values.

The concentrations are expressed in $\mu \mathrm{g} /$ liter (American "ppb's").

TABLE I

PESTICIDES AND RELATED SUBSTANCES IN THE RIVER RHINE AT RHINE KILOMETER 883 (SEPTEMBER 1969-MARCH 1972)

\begin{tabular}{|c|c|c|c|c|c|c|}
\hline Compound & $\begin{array}{l}\text { Incidence } \\
\text { rate } \\
(\%)\end{array}$ & $\begin{array}{l}\text { Detection } \\
\text { limit } \\
(\mu \mathrm{g} / \mathrm{l})\end{array}$ & $\begin{array}{l}\text { Average } \\
(\mu g / l)\end{array}$ & $\begin{array}{l}\text { Median } \\
(\mu g / l)\end{array}$ & $\begin{array}{l}\text { Upper and } \\
\text { lower deciles } \\
(\mu \mathrm{g} / l)\end{array}$ & $\begin{array}{l}\text { Minimum and } \\
\text { maximum value } \\
(\mu \mathrm{g} / \mathrm{l})\end{array}$ \\
\hline$\alpha-\mathrm{BHC}$ & 96 & 0.01 & 0.15 & 0.12 & $0.03-0.21$ & $<0.01-0.48$ \\
\hline$\gamma-\mathrm{BHC}$ & 95 & 0.01 & 0.10 & 0.07 & $0.01-0.15$ & $<0.01-0.34$ \\
\hline $\mathrm{HCB}$ & 98 & 0.01 & 0.13 & 0.09 & $<0.01-0.19$ & $<0.01-0.52$ \\
\hline Heptachlor & 3 & 0.01 & $<0.01$ & $<0.01$ & $<0.01-<0.01$ & $<0.01-0.04$ \\
\hline -epoxyd & 5 & 0.01 & $<0.01$ & $<0.01$ & $<0.01-<0.01$ & $<0.01-0.06$ \\
\hline Aldrin & 0 & 0.01 & $<0.01$ & $<0.01$ & $<0.01-<0.01$ & $<0.01-<0.01$ \\
\hline Dieldrin & 43 & 0.01 & $<0.01$ & $<0.01$ & $<0.01-0.02$ & $<0.01-0.08$ \\
\hline Endrin & 2 & 0.01 & $<0.01$ & $<0.01$ & $<0.01-<0.01$ & $<0.01-0.07$ \\
\hline Endosulfan $(\alpha+\beta)$ & 75 & 0.01 & 0.10 & $<0.01$ & $<0.01-0.29$ & $<0.01-0.88$ \\
\hline$p, p^{\prime}-\mathrm{DDT}$ & 12 & 0.02 & $<0.02$ & $<0.02$ & $<0.02-0.02$ & $<0.02-0.17$ \\
\hline$o, p^{\prime}-\mathrm{DDT}$ & 15 & 0.02 & $<0.02$ & $<0.02$ & $<0.02-<0.02$ & $<0.02-0.07$ \\
\hline$p, p^{\prime}-\mathrm{DDD}$ & 15 & 0.01 & $<0.01$ & $<0.01$ & $<0.01-<0.01$ & $<0.02-0.03$ \\
\hline$p, p^{\prime}-\mathrm{DDE}$ & 10 & $<0.01$ & $<0.01$ & $<0.01$ & $<0.01-<0.01$ & $<0.01-0.12$ \\
\hline $\begin{array}{l}\text { Cholinesterase } \\
\text { inhibitors }^{\mathbf{a}}\end{array}$ & 100 & 0.02 & 1.14 & 0.48 & $0.14-2.2$ & $0.04-15.7$ \\
\hline
\end{tabular}

as paraoxon. 
(a) The $\mathrm{C}_{6}$-compounds are nearly always present. If one compares the values reported in Table I with the values for other Dutch surface waters (Table II), the polluted state of the river Rhine is strikingly evident. It is noteworthy, that the concentrations of the by-product $\alpha-\mathrm{BHC}$ are higher than those of the insecticide proper, $\gamma$-BHC. This must mean that, either significant amounts of technical, $\alpha$-BHC containing products are still used alongside the Rhine, or that industry, rather than agriculture, is the main source of pollution. Also, the high concentrations of HCB can scarcely be explained by the limited use of this compound as a fungicide.

The presence of these $\mathrm{C}_{6}$-compounds is of concern, as these substances are persistent and are not easily removed during the processing to drinking water.

(b) From the group of alicycles, in the first place, endosulfan merits discussion. After the first "wave" in June-July $1969^{2}$ a second wave occurred in the autumn of the same year. This second wave was caused by the introduction of new endosulfan, that could be derived inter alia from the $\alpha: \beta$ ratio. Since July 1970 , however, the endosulfan concentrations in the Rhine have decreased to insignificant levels ${ }^{6}$.

Dieldrin has regularly been found. The concentrations are low, and the incidence rate, compared to the incidence rates found in agricultural surface waters, is not very high ( $c f$. Table II).

TABLE II

AVERAGE CONTENT $(\mu \mathrm{g} / \mathrm{l})$ OF SOME PESTICIDES AND RELATED SUBSTANCES IN DUTCH SURFACE WATERS

\begin{tabular}{|c|c|c|c|}
\hline Compound & Rhine & Maas & $\begin{array}{c}\text { Other surface } \\
\text { waters }\end{array}$ \\
\hline$\alpha-\mathrm{BHC}$ & 0.15 & 0.01 & 0.01 \\
\hline$\gamma-\mathbf{B H C}$ & 0.10 & 0.02 & 0.01 \\
\hline HCB & 0.13 & 0.01 & $<0.01$ \\
\hline Dieldrin & $<0.01$ & 0.01 & 0.01 \\
\hline $\begin{array}{l}\text { Cholinesterase } \\
\text { inhibitors } \\
\text { (as paraoxon) }\end{array}$ & 1.14 & 0.13 & 0.10 \\
\hline
\end{tabular}

The other organochlorine pesticides are of still less significance in the total pollution in the Rhine, which is fortunate, as some of these compounds are extremely toxic to fish.

The DDT-complex is in an intermediate position between the $\mathrm{C}_{6}$-compounds and the alicycles. The concentrations found are not alarming, and it should be noted that DDT is easily removed during the processing to drinking water.

(d) Cholinesterase inhibitors are present in significant amounts in all samples investigated. This is, as illustrated in Table II, again typical for the Rhine and its tributaries; in the other Dutch surface waters the average cholinesterase inhibition is about ten times lower. 
On the thin-layer chromatograms it can be shown that 5-6 different cholinesterase inhibitors are regularly present. The identification of these compounds and more detailed information on the occurrence of cholinesterase inhibitors in Dutch surface waters will be given in Part II of this series ${ }^{7}$.

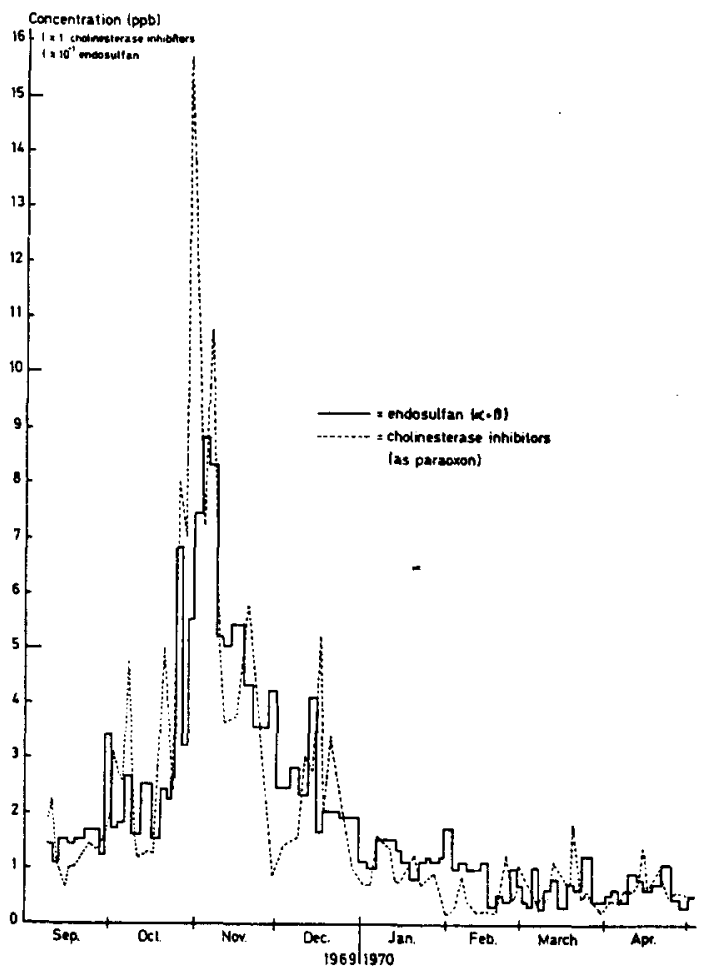

Fig. 1. Endosulfan ("second wave") and cholinesterase inhibitors in the river Rhine, Septem ber 1969-April 1970.

Simultaneously with the second endosulfan wave in the autumn of 1969 , a wave of cholinesterase inhibition has been found (Fig. 1). The origin of this wave is not known (N.B., endosulfan has no cholinesterase-inhibiting properties).

The presence of cholinesterase-inhibiting substances in surface waters must be principally taken as unfavourable, as the cholinesterase activity is intimately related to the basic conditions of life in the water environment. The cholinesterase inhibitors in the river Rhine also adversely affect the quality of the drinking water, as these substances are only partly removed by conventional processing methods.

\section{ACKNOWLEDGEMENT}

I thank my colleague Dr. A. G. Rauws of the Laboratory for Pharmacology in the same Institute for his continued help in performing the Auto-Analyzer determinations. 


\section{REFERENCES}

1 Pesticide Analytical Manual, U.S. Govt. Printing Office, Washington D.C., revised edition 1971, sections 121.3 and $211.14 \mathrm{~d}$.

2 P. A. Greve and S. L. Wit, J. Water Pollut. Contr. Fed., 43 (1971) 2338.

3 H. Ackermann, Nahrung, 10 (1966) 273.

4 D. C. Leegwater and H. W. van Gend, J. Sci. Food Agr., 19 (1968) 513.

5 G. F. Ernst and F. Schuring, J. Chromatogr., 49 (1970) 325.

6 P. A. Greve and S. L. Wit, Chem. Weekbl., 67 (1971) 7.

7 Part II, P. A. Greve and J. Freudenthal, Sci. Total Environ., to be published. 